\title{
SKIN LESIONS IN ENVENOMING BY CNIDARIANS (PORTUGUESE MAN-OF-WAR AND JELLYFISH): ETIOLOGY AND SEVERITY OF ACCIDENTS ON THE BRAZILIAN COAST
}

\author{
Vidal HADDAD JUNIOR(1), Fábio Lang da SILVEIRA(2) \& Álvaro Esteves MIGOTTO(3)
}

\begin{abstract}
SUMMARY
This work attempts to establish dermatological identification patterns for Brazilian cnidarian species and a probable correlation with envenoming severity. In an observational prospective study, one hundred and twenty-eight patients from the North Coast region of São Paulo State, Brazil were seen between 2002 and 2008. About $80 \%$ of these showed only local effects (erythema, edema, and pain) with small, less than $20 \mathrm{~cm}$, oval or round skin marks and impressions from small tentacles. Approximately $20 \%$ of the victims had long, more than $20 \mathrm{~cm}$, linear and crossed marks with frequent systemic phenomena, such as malaise, vomiting, dyspnea, and tachycardia. The former is compatible with the common hydromedusa from Southeast and Southern Brazil (Olindias sambaquiensis). The long linear marks with intense pain and systemic phenomena are compatible with envenoming by the box jellyfish Tamoya haplonema and Chiropsalmus quadrumanus and the hydrozoan Portuguese man-of-war (Physalis physalis). There was an association between skin marks and probable accident etiology. This simple observation rule can be indicative of severity, as the Cubozoa Class (box jellyfish) and Portuguese man-of-war cause the most severe accidents. In such cases, medical attention, including intensive care, is important, as the systemic manifestations can be associated with death.
\end{abstract}

KEYWORDS: Cnidarians; Box jellyfish; Portuguese man-of-war; Human envenoming; Skin marks, Brazil.

\section{INTRODUCTION}

Cnidarians are marine animals with a round body, tentacles, and defense organelles (nematocysts) in cells called cnidocytes. Nematocysts are thin tubules with a micro needle in the extremity that can deeply penetrate the victim's skin, injecting venom. Nematocysts are mainly present in the tentacles and are used to hunt and for defense. Nematocysts inject toxins that can include polypeptides which, in some species, may have neurotoxic and dermatonecrotic reaction in humans, causing severe envenoming. In large jellyfish nematocysts, millions of these are present on tentacles and discharge by an osmotic process during the contact with the victim.

The main classes of cnidarians causing human envenoming are: Anthozoa (anemones and corals), Hydrozoa (Portuguese man-of-war and hydroids) (Fig. 1), Scyphozoa (the true jellyfish) (Fig. 2) and Cubozoa (the box jellyfish, responsible for the most severe envenoming in humans) (Fig. 3). All these animals possess cnidocytes and the severity of the accidents varies with the quantity of nematocysts discharged and size of the victim (body surface area - children are at higher risk).

In a study on injuries caused by aquatic animals, cnidarians caused nearly $25 \%$ of 250 envenoming cases in Brazilian bathers in the Southeast region of $\mathrm{Brazil}^{2-7}$. Clinical manifestations of the envenoming generally follow a clear pattern of symptoms and signs. The most characteristic features are linear erythematous plaques and intense pain, which are present from the moment of contact. Cnidarian species in the West Atlantic Ocean (Brazil, Caribbean, USA) are similar and rarely provoke systemic manifestations, but a minority of patients experience systemic effects that can include dyspnea, malaise, arterial hypotension, and cardiac arrhythmias ${ }^{2,3,4,5,6}$.

First aid is controversial: iced saltwater compress or cold packs can be used $^{2,3,4,5,6}$. Application of freshwater can discharge integral nematocysts by osmosis. This measure has an analgesic effect and should be applied while still at the beach. However, there is a recent report of a randomized controlled study in Australia showing that exposure of the affected part to hot water at $45^{\circ} \mathrm{C}$ for 20 minutes is a measure more effective than immersion in cold water in the treatment for Physalia sp envenomation ${ }^{7}$. In this study patients used a hot shower rather than immersion of the stung area.

When the animal is a cubomedusa (Tamoya haplonema or Chiropsalmus quadrumanus) it is very important to apply vinegar compresses or bathe the sting site with copious amounts of vinegar to inactivate still undischarged nematocysts. In accidents caused by 
HADDAD JUNIOR, V.; SILVEIRA, F.L. \& MIGOTTO, A.E. - Skin lesions in envenoming by cnidarians (Portuguese man-of-war and jellyfish): etiology and severity of accidents on the Brazilian coast. Rev. Inst. Med. Trop. São Paulo, 52(1): 47-50, 2010.

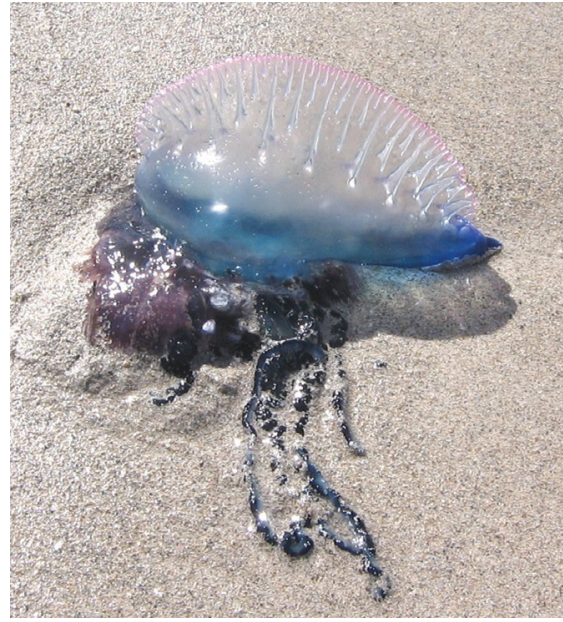

Fig. 1 - Portuguese man-of-war (Physalia physalis), a hydrozoa capable of causing severe envenoming in humans. Photograph: Itamar Alves Martins.

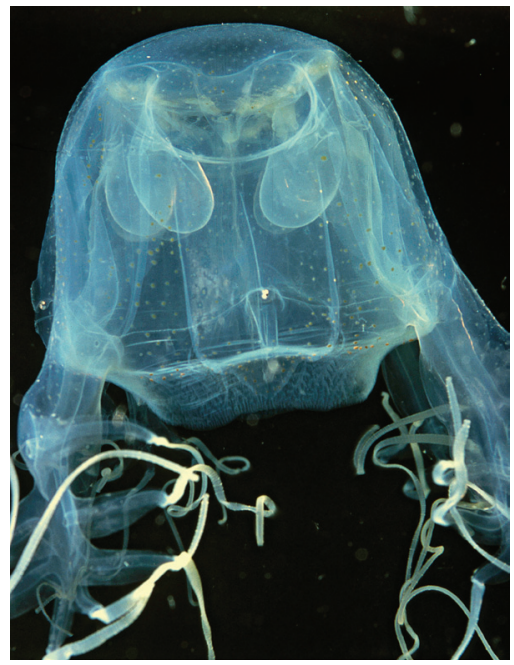

Fig. 2 - Chiropsalmus quadrumanus, an important cubozoan in the genesis of severe human envenoming along the Brazilian Coast. Photograph: Álvaro Esteves Migotto.

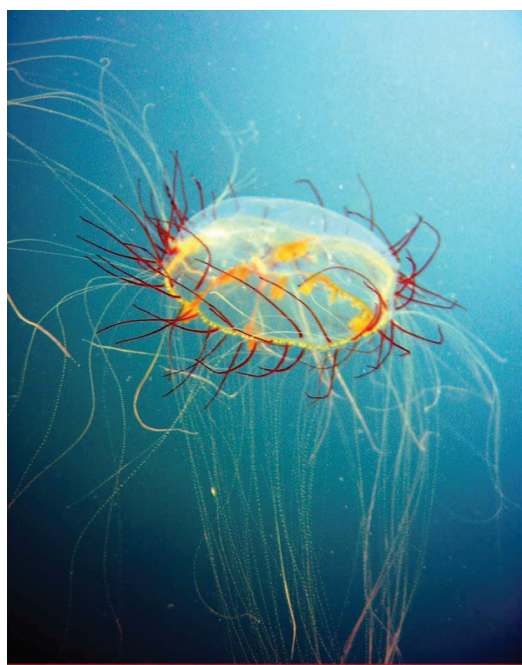

Fig. 3 - Olindias sambaquiensis, a small hydrozoa medusa associated to the majority of envenomings in Southeast Atlantic. Photograph: Fábio Lang da Silveira.

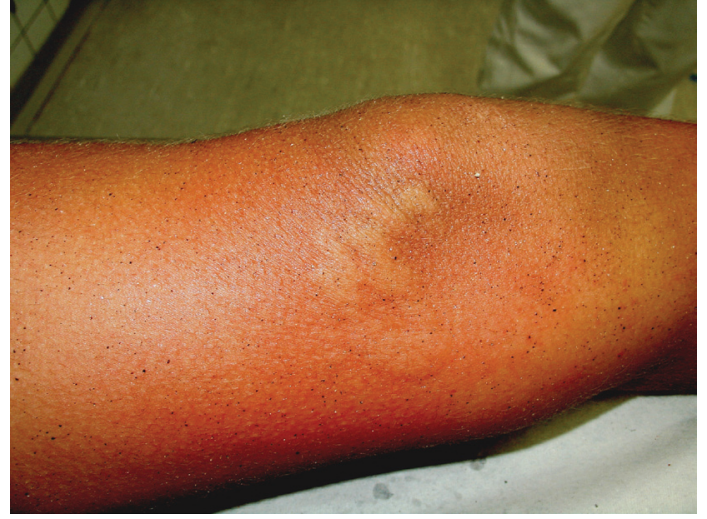

Fig. 4 - Erythematous plaques showing the impression of the cnidarian body are suggestive of envenoming caused by Olindias sambaquiensis. Photograph: Vidal Haddad Junior.

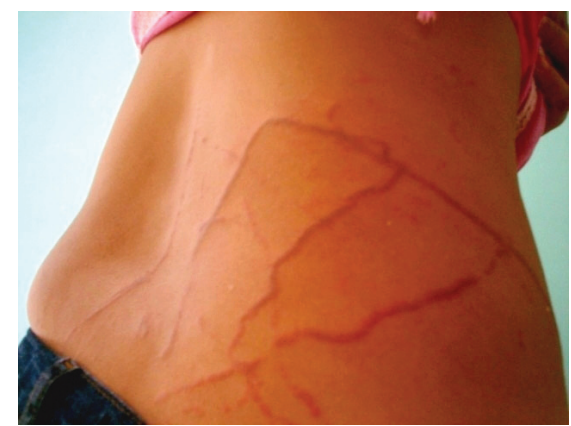

Fig. 5 - Typical envenoming by the box jellyfish or Portuguese man-of-war. Note the intercrossed lines larger than $20 \mathrm{~cm}$. Photograph: Vidal Haddad Junior.

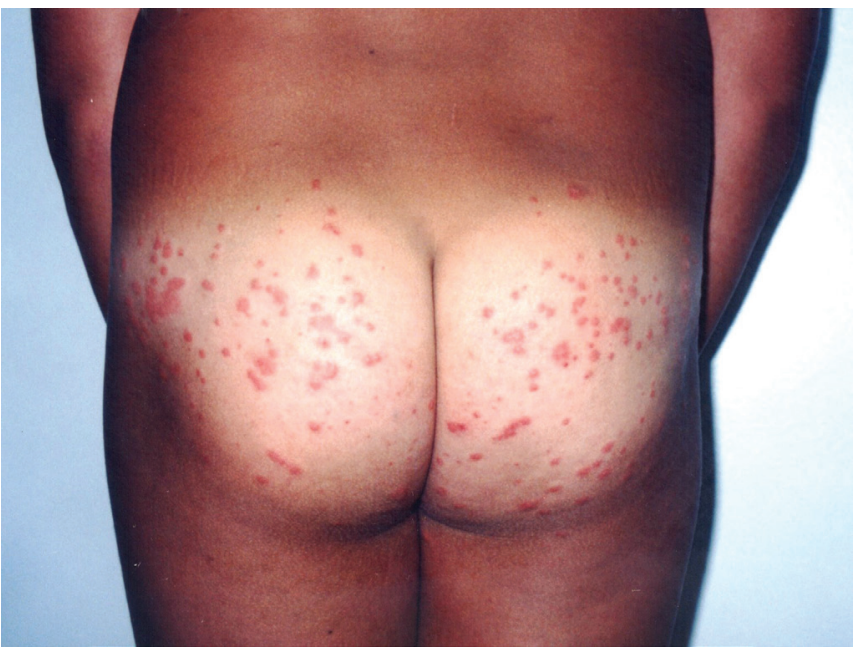

Fig. 6 - Classic skin lesions under swimwear caused by Linuche unguiculata larvae (seabather's eruption). Photograph: André Luís Rossetto.

Portuguese man-of-war and Olindias sambaquiensis (a small hydrozoan responsible for the majority of the injuries in Southeast and South regions of Brazil), this measure is not so certain, as in vitro experiments have shown that nematocysts are discharged from some Portuguese man-of-war specimens when bathed in vinegar or alcohol solutions. In our experience, the application of vinegar is a good first aid measure in accidents by all cnidarians on the Brazilian Coast ${ }^{2-6}$. 


\section{OBJECTIVES}

This work attempts to establish standards for dermatological identification of skin lesions caused by Brazilian species of cnidarians, and probable correlations with the severity of the envenoming ${ }^{6}$.

\section{PATIENTS AND METHODS}

One hundred twenty-eight patients were observed in a prospective study conducted at Ubatuba Hospital (North São Paulo State Coast, Southeast Brazil) over a six-year period (2002-2008). After receiving first aid to control pain, the patients answered a standard questionnaire and skin lesions were photographed. For the purpose of this study, the following aspects were studied; local signs and symptoms (erythema, edema, pain, blisters, skin necrosis), systemic manifestations and lesion extension on the victim body. On four occasions, the authors collected specimens of cnidarians using a boat and nets off the beaches where the envenoming occurred. The specimens collected were identified by the authors and were deposited in the Cnidarians Collection of the Zoology Department in the São Paulo State University. Skin scrapings to allow identification of the causative jellyfish from adherent nematocysts were not collected.

\section{RESULTS}

One hundred and nine patients $(79.98 \%)$ showed only local effects (erythema, edema, pain). In these cases, the skin marks were small, oval or round, sometimes with impressions of small tentacles (Fig. 4); length was less than $20 \mathrm{~cm}$. Twenty-four victims (17.39\%) presented long, linear, crossed marks, of more than $20 \mathrm{~cm}$, with frequent systemic effects, including malaise, vomiting, dyspnea, and tachycardia (Fig. 5). Another pattern was seen in a few cases; erythematous and itchy papules located in areas under swimwear (five cases or $3.62 \%$ ) (Fig. 6). The specimens collected off the beaches were Olindias sambaquiensis (fifty specimens) and Chiropsalmus quadrumanus (four specimens).

\section{DISCUSSION}

The pattern of small rounded marks is compatible with a very common hydrozoan from Southeast and Southern Brazil (Olindia sambaquiensis), which causes minor local effects. The long linear marks, which are followed by intense pain and systemic effects, are compatible with envenoming by cubomedusae, Tamoya haplonema and Chiropsalmus quadrumanus, and the hydrozoan Portuguese man-of-war (Physalis physalis). The presence of the red-purple floating Portuguese man-of-war in the contact area is very characteristic and its absence in the presence of long intercrossed lines and intense pain is indicative of Cubozoans. Papules under bathing clothes are compatible with a characteristic dermatitis, seabather's eruption, caused by planulae from a small jellyfish (Linuche unguiculata). A limitation of this study was the inability to link clinical effects directly to a causative jellyfish species, using nematocyst identification in skin scrapings samples.

\section{CONCLUSIONS}

There was an association between skin marks and probable etiology and severity of accidents in the West Atlantic Ocean; extensive sting (tentacle contact) tracks with significant local pain and occasional systemic manifestations indicate cnidarians of the Cubozoa Class (box jellyfish) and Portuguese man-of-war, animals that cause the most severe accidents $^{2-6}$. Contacts with intense pain and small round marks are compatible with envenoming by Olindias sambaquiensis. Erythematous and itchy papules (not painful) indicate injuries caused by Linuche unguiculata, the "seabather's eruption"2. This simple observation rule is indicative of severity, as the cubozoans and Portuguese man-of-war cause the most severe envenoming, especially if there are systemic manifestations $^{1-7}$.

\section{RESUMO}

Lesões dermatológicas observadas nos acidentes por cnidários (águas-vivas e caravelas): etiologia e gravidade dos envenenamentos no litoral do Brazil

Cnidários são animais que apresentam no corpo (especialmente nos tentáculos) organelas de defesa chamadas nematocistos, podendo causar graves envenenamentos. Este trabalho procura estabelecer padrões clínicos auxiliares na identificação das espécies de cnidários brasileiros e pesquisar provável correlação das lesões na pele com a gravidade do acidente. Cento e vinte e oito pacientes foram observados no Pronto-Socorro de Ubatuba (Litoral Norte do estado de São Paulo) em período de seis anos (2002-2008). Cerca de $80 \%$ dos acidentes mostraram apenas manifestações locais (dor, eritema e edema). Nestes casos, as marcas cutâneas foram pequenas, ovais e arredondadas, algumas vezes com impressões de pequenos tentáculos. As marcas foram menores que $20 \mathrm{~cm}$. Aproximadamente $20 \%$ das vítimas tinham lesões longas, lineares e cruzadas, maiores que $20 \mathrm{~cm}$ com frequente observação de fenômenos sistêmicos, como mal estar, vômitos, dispnéia e taquicardia. O padrão das marcas arredondadas e curtas é compatível com hidromedusa muito comum nas regiões Sudeste e Sul do Brasil (Olindia sambaquiensis), que causa acidentes de pequena magnitude. As marcas longas e lineares, associadas à dor intensa e fenômenos sistêmicos, são compatíveis com envenenamento pelas cubomedusas Tamoya haplonema e Chiropsalmus quadrumanus e o hidrozoário Physalis physalis, a caravela. Houve associação entre as marcas cutâneas e a provável etiologia do acidente. Esta regra simples de observação clínica pode ter valor clínico, uma vez que a Classe Cubozoa (vespas-do-mar) e as caravelas causam os acidentes mais graves. Nestes casos, a atenção médica deve ser redobrada, incluindo cuidados intensivos, uma vez que fenômenos sistêmicos podem se associar a óbitos.

\section{REFERENCES}

1. Cardoso JLC, França FOS, Wen FH, Malaque CMS, Haddad Jr V. Venomous animals in Brazil: biology, clinics and therapeutic of the accidents. São Paulo: Editora Sarvier; 2004

2. Haddad Jr V, Cardoso JLC, Silveira FLS. Seabather's eruption: report of five cases in the Southeast Region of Brazil. Rev Inst Med Trop Sao Paulo. 2001;43:171-2.

3. Haddad Jr V, Silveira, FL, Cardoso JLC, Morandini AC. A report of 49 cases of cnidarian envenoming from southeastern Brazilian coastal waters. Toxicon. 2002;40:1445-50.

4. Haddad Jr V, Silva G, Rodrigues TC, Souza V. Injuries with high percentage of systemic findings caused by the cubomedusa Chiropsalmus quadrumanus (Cnidaria) in Southeast region of Brazil: report of ten cases. Rev Soc Bras Med Trop. 2003;36:84-5. 
HADDAD JUNIOR, V.; SILVEIRA, F.L. \& MIGOTTO, A.E. - Skin lesions in envenoming by cnidarians (Portuguese man-of-war and jellyfish): etiology and severity of accidents on the Brazilian coast. Rev. Inst. Med. Trop. São Paulo, 52(1): 47-50, 2010.

5. Haddad Jr V. Aquatic animals of medical importance. Rev Soc Bras Med Trop. 2003;36:591-7.

6. Haddad Jr V. Brazilian potentially dangerous aquatic animals: a medical and biological guide. São Paulo: Editora Roca; 2008. Marine Invertebrates; p. 12-28.
7. Loten C, Stokes B, Warsley D, Seymour, JE, Jiang S, Isbister GK. A randomized controlled trial of hot water $\left(45^{\circ} \mathrm{C}\right)$ immersion versus ice packs for pain relief in bluebottle stings. Med J Aust. 2006;4:329-33.

Received: 14 May 2009

Accepted: 27 November 2009 